\title{
PENGEMBANGAN TERAPI CERMIN PADA LATIHAN BERSEPEDA BERBASIS VIRTUAL REALITY UNTUK MENINGKATKAN GERAK MOTORIK EKSTREMITAS ATAS PASCA STROKE
}

\author{
I Putu Dody Lesmana ${ }^{1}$, Beni Widiawan ${ }^{2}$, Didit Rahmat Hartadi ${ }^{3}$, Muhammad Fuad Al Haris ${ }^{4}$ \\ ${ }^{1,2,3}$ Jurusan Teknologi Informasi, Politeknik Negeri Jember, ${ }^{4}$ Jurusan Teknik Informatika, Politeknik Negeri \\ Banyuwangi \\ Email: ${ }^{1,2,3}$ \{dody, beni, hartadidr\}@polije.ac.id, ${ }^{4}$ f_haris@poliwangi.ac.id
}

(Naskah masuk: 11 Juli 2018, diterima untuk diterbitkan: 28 September 2018)

\begin{abstract}
Abstrak
Latihan bersepeda berbasis virtual reality (VR-Bicycling) bagi penderita pasca stroke merupakan teknologi yang dikembangkan untuk meningkatkan gerak motorik otot pada ekstremitas bawah. Tetapi biasanya penderita pasca stroke juga mengalami hemiparesis pada ekstremitas atas dimana mengalami gangguan gerak dan menimbulkan rasa takut untuk menyentuh benda yang jauh. Penggunaan terapi cermin (Mirror Therapy-MT) merupakan bentuk terapi gerak motorik ekstremitas atas dengan mempengaruhi propriosepsi otak yang berfikir bahwa eksterimitas atas yang mengalami hemiparesis dapat bergerak baik. Dalam penelitian ini dikembangkan penerapan MT pada VR-Bicycling menggunakan Kinect sebagai sensor gerak lengan yang sakit untuk melatih gerak motorik ekstremitas atas pada penderita pasca stroke. Pengujian sistem melibatkan sepuluh penderita pasca stoke dengan hemiparesis pada ekstremitas atas. Setelah dilakukan uji coba sistem, dilakukan pengumpulan data dari pengguna berkaitan dengan operabilitas lengan virtual, konsentrasi pengguna dan konsistensi gerakan lengan virtual dalam mengevaluasi fungsionalitas sistem yang meliputi waktu tunda, perbedaan spasial antara gerakan lengan virtual dan lengan yang sakit, kontrol gerakan dari lengan virtual. Dari hasil evaluasi data menggunakan analisis faktor dengan oblique rotation diketahui bahwa variabel waktu tunda dan perbedaan spasial pada terapi ekstremitas atas menggunakan VR-Bicycling dengan MT merupakan dua variabel penting untuk mengontrol arah dan ketepatan gerakan lengan virtual pada lingkungan virtual.
\end{abstract}

Kata kunci: VR-Bicycling, MT, Kinect, operabilitas, kontrol, waktu tunda, perbedaan spasial

\section{DEVELOPMENT OF MIRROR THERAPY BASED VIRTUAL REALITY BICYCLING TO ENHANCE MOTOR FUNCTION FOR PERSON WITH UPPER EXTREMITY HEMIPARESIS}

\begin{abstract}
Virtual reality bicycling (VR-Bicycling) for a person post-stroke is built to train and strengthen motor function of lower extremity. Impaired motion of upper extremity is usually found in a condition of existing lower extremity hemiparesis in a person post-stroke who are known from a fear to touch or reach distant objects because of pain on his limb. The use of mirror therapy (MT) causes a person with upper extremity hemiparesis has ability to deceive the brain by viewing the movement of the reflection of normal limb in the mirror which are followed the movement of the missing limb. In this research, we have developed a VR-MT module combined with VRBicycling system using Kinect for pain limb movement detection to control virtual limb in the opposite side at virtual environment (VE) of VR-Bicycling. Ten persons post-stroke with upper extremity hemiparesis are involved in the experiment to test functionality of developed system. After therapy task execution, the data collection from the answer of questionnaire about operability of virtual limb, concentration when using VRBicycling with MT module, and consistency of the virtual limb during the movement the real limb to evaluate developed system functionality including time delay, spatial difference when operating virtual limb, virtual limb control, and tracking of movement. The evaluation result using factor analysis with oblique rotation shows that time delay and spatial difference have strong relationship to control virtual limb movement correctly during the task.
\end{abstract}

Keywords: VR-Bicycling, Kinect, operability, controllability, time delay, spatial difference 
Kondisi hemiparesis pada ekstremitas atas/lengan memerlukan penanganan serius pada penderita pasca stroke selain melalui tindakan medis juga diperlukan tindakan fisioterapi (Dohle dkk., 2009; Yavuzer dkk., 2008). Bentuk fisioterapi yang diterapkan seperti latihan Range-of-Motion (ROM) bilateral dan unilateral untuk tubuh bagian atas (Summers dkk., 2007), penggunaan bantuan gerakan dengan mekanika robotika (Masiero dkk., 2007), latihan Constraint Induced Movement TherapyCIMT (Chiu and Ada, 2016) dilakukan secara rutin untuk melatih hemiparesis dan meningkatkan ROM. Tetapi penerapan latihan fisik untuk mengatasi hemiparesis biasanya kurang dijalankan secara mandiri oleh penderita pasca stroke karena kendala rasa sakit yang timbul dan kurangnya motivasi diri walaupun biasanya penderita patuh pada arahan dokter atau fisioterapis saat memeriksakan diri di rumah sakit (Wu dkk., 2013).

Dari hasil penelitian yang dilakukan oleh (De Vries \& Mulder, 2007; Ramachandran, 2005), penggunaan ilusi optik cermin memberikan stimulasi visual kepada otak yang dapat mempengaruhi peningkatan ROM dari fungsi motorik ekstremitas atas sehingga menghasilkan intervensi terapi baru non-invasif yang disebut terapi cermin (Mirror Therapy-MT) bagi penderita pasca stroke untuk ekstrimitas atas. MT dilakukan menggunakan kotak yang dipasangi cermin pada midsagittal plane dimana penderita dapat melihat bayangan dari lengan normal seolah-olah bayangan tersebut menggantikan lengan yang sakit. Dalam MT, penglihatan mengesampingkan hal yang menyebabkan sensasi terkuat dalam otak, yaitu rasa sakit sehingga secara tidak langsung otak akan mengirimkan sinyal pada lengan yang sakit untuk bergerak mengikuti stimulus otak. Keberhasilan MT ditentukan oleh seberapa besar fokus dan konsentrasi pikiran untuk melihat ilusi sebagai kondisi nyata (Lamont dkk., 2011). Oleh karena itu, penggunaan teknologi Virtual Reality (VR) sebagai media MT memberikan sensasi yang lebih mendalam pada otak (immersion) dalam memperkuat ilusi sehingga meningkatkan keberhasilan latihan terapi ekstremitas atas bagi penderita pasca stroke (Fukumori dkk., 2014; Lamont dkk., 2011).

(Sato dkk., 2010) menerapkan VR-MT nonimmersive untuk meringankan penyakit Complex Regional Pain Syndrome (CRPS) dan setelah terapi berakhir gejala CRPS tidak tampak kembali. (Fukumori dkk., 2014) mengembangkan sistem VRMirror Visual Feedback (VR-MVF) untuk terapi ekstremitas atas di rumah sakit Universitas Okayama, Jepang. Sistem ini membenamkan sensor flex pada sarung tangan (data glove) untuk mengukur gerakan jari tangan dan sensor gyroscope yang diletakkan ditengah sarung tangan untuk mendeteksi pergerakan tangan pengguna. Lengan bawah yang sakit digunakan untuk memindahkan obyek virtual sedangkan lengan bawah yang normal digunakan untuk mengontrol cara meletakkan obyek. Penggunaan perangkat tambahan pada lengan ketika menggunakan terapi VR-MT masih menimbulkan ketakutan pada penderita hemiparesis pada ekstremitas atas karena adanya perasaan sakit pada lengan.

Penggunaan terapi hemiparesis pada ekstremitas atas biasanya juga ditambahkan pada penderita pasca stroke yang mengalami hemiparesis pada ekstremitas bawah. (Deutsch dkk., 2013; Farjadian dkk., 2013; Ranky dkk., 2010) menambahkan latihan ekstremitas atas bagi penderita pasca stroke pada VR-Bicycling dengan sepeda statis menggunakan pegangan tangan pada sepeda statis (handle bar) yang ditanamkan sensor tekanan hidrolis untuk mengontrol keseimbangan sepeda pada lingkungan virtual (Virtual Environment-VE) melalui pengukuran kekuatan genggaman tangan (hand grasping). Tetapi, terapi hemiparesis pada ekstremitas atas VR-Bicycling ini kurang memberikan keleluasaan gerak ROM lengan. Sedangkan penerapan MT atau VR-MT pada terapi hemiparesis untuk ekstremitas atas penderita pasca stroke menggunakan sepeda statis masih belum diterapkan.

Untuk mengatasi masalah terbatasnya gerak ROM dan timbulnya rasa ketakutan ketika lengan menyentuh sesuatu benda bagi penderita pasca stroke yang menderita hemiparesis pada ekstremitas atas ketika menggunakan latihan bersepeda statis, maka Dalam penelitian ini dikembangkan penerapan MT pada $V R$-Bicycling menggunakan Kinect sebagai sensor gerak lengan yang sakit untuk melatih gerak motorik ekstremitas atas pada penderita pasca stroke. Evaluasi sistem dilakukan untuk mengetahui fungsionalitas gerakan lengan virtual pada terapi MT ketika menjalankan terapi $V R$-Bicycling yang berupa pengukuran operabilitas lengan virtual terhadap lengan yang sakit, konsentrasi pengguna ketika menggunakan sistem, kontrol gerakan dari lengan virtual, waktu tunda, dan perbedaan spasial antara gerakan lengan yang sakit dengan gerakan lengan virtual.

\section{METODE PENELITIAN}

\subsection{Desain Penelitian}

Penelitian ini menggunakan metode cross sectional yang melibatkan penderita pasca stroke sebagai subyek penelitian. Penelitian ini telah mendapatkan persetujuan dari komisi etik penelitian dari Rumah Sakit dr. Soebandi Jember dan semua subyek penelitian telah menyetujui dan menandatangani informed consent untuk terlibat sampai penelitian ini selesai dilakukan. 


\subsection{Modul VR-Bicycling dengan MT}

Modul pendukung sistem VR-Bicycling untuk terapi ekstremitas atas berbasis MT terdiri dari modul VR-Bicycling, komputer, speaker stereo, proyektor untuk menampilkan VE, sepeda statis, sensor load cell, sensor encoder, sensor jantung, dan mikrokontroler Arduino.

\subsection{Desain Sistem}

VE dibuat menggunakan Unity 5.4 ${ }^{\mathrm{TM}}$ dengan bahasa pemrograman C\#. Obyek dalam VE dirancang untuk melatih gerak motorik ekstremitas atas dimana lengan yang sakit menjadi refleksi lengan virtual dalam VE yang bergerak menangkap apel atau menghindari bom sepanjang lintasan bersepeda. Pemilihan obyek dalam VR-Bicycling digunakan untuk memberikan sensasi lebih mendalam (immersion) untuk menstimulus kerja otak, dengan desain sebagai berikut:

- Sudut pandang (Field of View-FoV): Besar sudut pandang pengguna di VE menentukan akurasi dari gerakan pengguna dan sensasi ketika memainkan permainan VR-Bicycling. Nilai ideal sudut pandang dalam VE terletak antara $80^{\circ}$ sampai dengan $200^{\circ}$ (Powell \& Stevens, 2013). Dalam penelitian ini digunakan sudut pandang $80^{\circ}$.

- Perbedaan frekuensi spasial antara gerakan di VE dan dunia nyata: Manipulasi frekuensi spasial dapat menimbulkan perbedaan gerakan antara di VE dan dunia nyata menjadi terasa lebih cepat atau lebih lambat (Banton dkk., 2005; Holden, 2005). Dalam penelitian ini dipilih frekuensi spasial rendah dengan translation gain 0.4 sehingga diperoleh simulasi VR-Bicycling yang lebih nyata.

- Penskalaan obyek: penskalaan obyek di VE yang proporsional dengan ukuran nyata dapat mempengaruhi persepsi diri terhadap gerakan dalam VE (Powell \& Stevens, 2013). Dalam penelitian ini dilakukan penskalaan proporsional antara obyek di VE terhadap ukuran obyek di dunia nyata.

- Pemilihan warna dan tekstur: Pemilihan kontras warna dan tekstur memperbaiki persepsi diri terhadap gerakan dalam VE. Dalam penelitian ini dilakukan pemilihan warna yang memiliki kontras yang tinggi untuk membedakan jalan, sepeda, langit, apel, bom, pengguna, pelatih, dan tekstur VE.

- Umpan balik visual dan audio: Penggunaan bantuan visual dan audio pada MT memberikan peningkatan ROM ekstremitas atas bagi penderita pasca stroke (Cantero-Téllez dkk., 2018). Kedua elemen ini meningkatkan operabilitas, konsentrasi, dan konsistensi gerakan lengan virtual selama terapi $V R$ Bicycling berlangsung. Dalam penelitian ini, umpan balik visual untuk MT di desain menggunakan obyek apel dan obyek bom yang dibuat menggunakan Unity. Obyek apel dan bom disusun sedemikian rupa sepanjang lintasan sepeda virtual yang dapat dicapai oleh lengan virtual sesuai kemampuan ROM dari lengan lain yang sakit. Sedangkan umpan balik audio dibentuk menggunakan metronome untuk memperkecil waktu tunda dan meningkatkan konsentrasi pikiran. Luaran audio dikeluarkan melalui dua speaker desktop stereo.

Tujuan dari desain sistem adalah bagaimana membuat VR-Bicycling yang mendukung terapi hemiparesis untuk ekstrimitas atas menggunakan konsep MT seperti ditunjukkan Gambar 1. Desain pemandangan, jalan, pohon, rumah, langit yang membentuk VE dibuat menggunakan editor terrain Unity 5.4. Obyek avatar dilengkapi dengan pemberian tulang (rigging) dan sepeda dibuat menggunakan Blender yang di ekspor ke Unity 5.4. Masukan sistem MT pada VR-Bicycling diperoleh dari Kinect sebagai sensor gerak (motion capture) yang menghasilkan refleksi lengan yang sakit di VE secara mirroring. Script VR-Bicycling ditulis dalam bahasa pemrograman $C \#$ yang dihubungkan dengan Microsoft Kinect SDK untuk sistem operasi Microsoft Windows dan Kinect Unity Plugin.

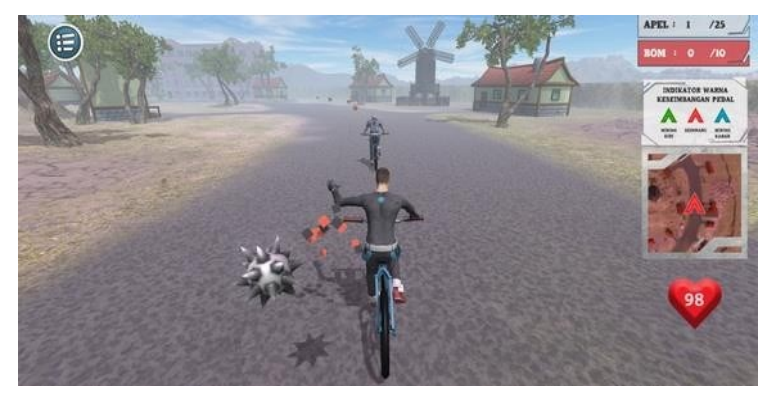

Gambar 1. Desain sistem VR-Bicycling dengan MT untuk terapi hemiparesis pada ekstremitas atas penderita pasca stroke

\subsection{Pengguna Sistem}

Pengujian sistem VR-Bicycling dengan tambahan modul MT untuk terapi ekstremitas atas melibatkan sepuluh penderita pasca stroke yang dipilih oleh dokter fisioterapi Rumah Sakit dr. Soebandi Jember dengan karakteristik sebagai berikut: 1. usia 50-70 tahun; 2. di diagnosis mengalami hemiparesis ekstremitas atas karena stroke oleh dokter fisioterapi; 3. memiliki kemampuan melakukan latihan fisik. Sedangkan pengguna yang tidak memenuhi kriteria sistem, yaitu: 1. menderita gangguan pendengaran atau gangguan penglihatan termasuk buta warna atau menderita keduanya; 2. memiliki rekam jejak pernah mengalami trauma otak, gangguan sistem saraf (neurologis), parkinson; 3. kondisi kesehatan tidak stabil termasuk gangguan muskuloskeletal. 


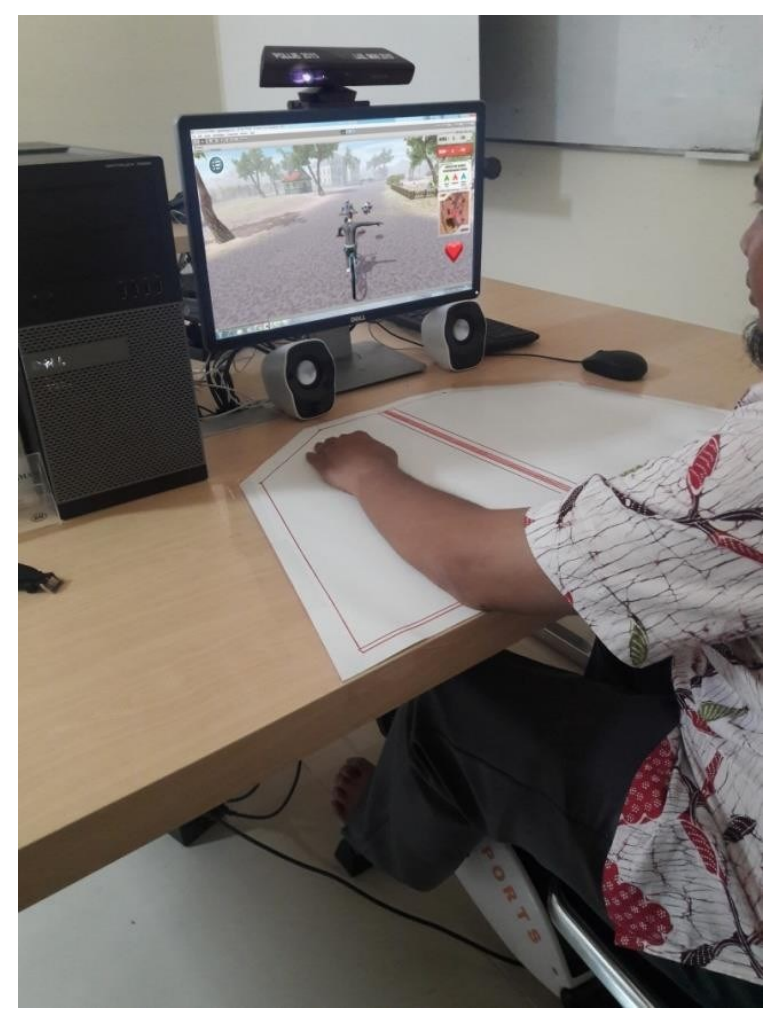

Gambar 2. Uji coba VR-Bicycling dengan modul MT untuk terapi ekstremitas atas dimana penderita pasca stroke mengalami kekakuan otot pada lengan kiri

\subsection{Pengumpulan dan Analisis Data}

Untuk mengetahui variabel apa saja yang mempengaruhi fungsionalitas sistem dapat dilakukan pengumpulan data dari pengguna sistem menggunakan lembar pertanyaan yang berisi variabel-variabel independen yang akan diamati korelasinya (Anggoro, 2018). Penentuan variabel yang menentukan fungsionalitas dari terapi MT pada VR-Bicycling berhubungan dengan operabilitas lengan virtual, konsentrasi pengguna, kontrol, waktu tunda, rekaman terapi MT, dan perbedaan spasial selama melakukan terapi.

Penderita pasca stroke melakukan terapi ekstremitas atas selama satu putaran, dimana jika pengguna berhasil menangkap apel maka nilai bertambah 10, sebaliknya jika bom yang ditangkap akan mendapatkan pengurangan nilai sebesar 20 . Cara kerja sistem, penderita pasca stroke menggerakkan salah satu lengan yang mengalami hemiparesis pada meja sambil bersepeda. Setelah terapi dilakukan, maka penderita pasca stroke harus menjawab daftar pertanyaan sebagai berikut:

1) Berapa banyak pengguna sistem dapat mengontrol dengan baik lengan virtual pada monitor untuk menangkap apel atau menghindari bom?

2) Berapa banyak pengguna dapat fokus pada monitor selama permainan berlangsung?

3) Berapa banyak pengguna dapat menjalankan lengan virtual secara baik (tidak terpatahpatah)?
4) Apakah gerakan lengan virtual serupa dengan gerakan lengan yang mengalami kekakuan otot?

5) Berapa banyak terjadinya waktu tunda yang mempengaruhi gerakan lengan virtual?

6) Apakah lengan virtual bergerak secara mirroring mengikuti arah dari gerakan lengan yang mengalami kekakuan otot secara sebagai pengontrol?

7) Berapa banyak pengaruh perbedaan spasial ketika menjalankan lengan virtual?

8) Apakah pengguna merasakan adanya perubahan gerakan pada lengan virtual saat lengan yang mengalami kekakuan otot berada dalam kondisi tidak bergerak?

9) Berapa banyak terjadinya perubahan gerakan pada lengan virtual saat lengan yang mengalami kekakuan otot berada dalam kondisi tidak bergerak?

Pertanyaan nomor 1-3 berhubungan dengan operabilitas, konsentrasi pengguna terhadap jalannya sistem, kelancaran operasi sistem untuk berjalan normal (natural). Sedangkan pertanyaan nomor 4 dan 5 berhubungan dengan waktu tunda antara gerakan lengan yang mengalami kekakuan otot terhadap kontrol gerakan lengan virtual. Pertanyaan 6 dan 7 berhubungan dengan rekaman terapi MT pengguna pada VR-Bicycling selama satu putaran. Dan pertanyaan nomor 8 dan 9 berhubungan dengan perbedaan spasial selama uji coba. Pertanyaan nomor 4, 6, dan 8 memerlukan jawaban "Ya" atau "Tidak", sedangkan pertanyaan lainnya dinilai dalam skala 0-5 dimana semakin besar nilainya maka berarti semakin memiliki pengaruh.

Rekaman terapi MT pada VR-Bicycling di evaluasi dari seberapa banyak penderita pasca stroke dapat menggerakkan lengan virtual untuk menangkap apel atau menghindari bom. Evaluasi data dari pertanyaan nomor $1,2,3,5,7$, dan 9 dilakukan menggunakan metode analisis faktor (factor analysis) untuk menemukan variabelvariabel apa saja yang mempengaruhi kontrol lengan virtual untuk terapi ekstremitas atas penderita pasca stroke pada VR-Bicycling dengan MT. Analisis faktor dilakukan menggunakan aplikasi SPSS 17 dengan ekstraksi faktor menggunakan Principal Component Analysis (PCA) dan rotasi faktor (oblique rotation) menggunakan Promax with Kaiser Normalization untuk menggolongkan posisi dari suatu variabel termasuk pada kelompok faktor yang mana.

\section{HASIL DAN PEMBAHASAN}

Gambar 3 menunjukkan nilai rata-rata dan standar deviasi jawaban dari pertanyaan 1, 2, 3, 5, 7, dan 9 yang di isi oleh sepuluh penderita pasca stroke setelah melakukan terapi ekstremitas atas menggunakan VR-Bicycling dengan MT. 


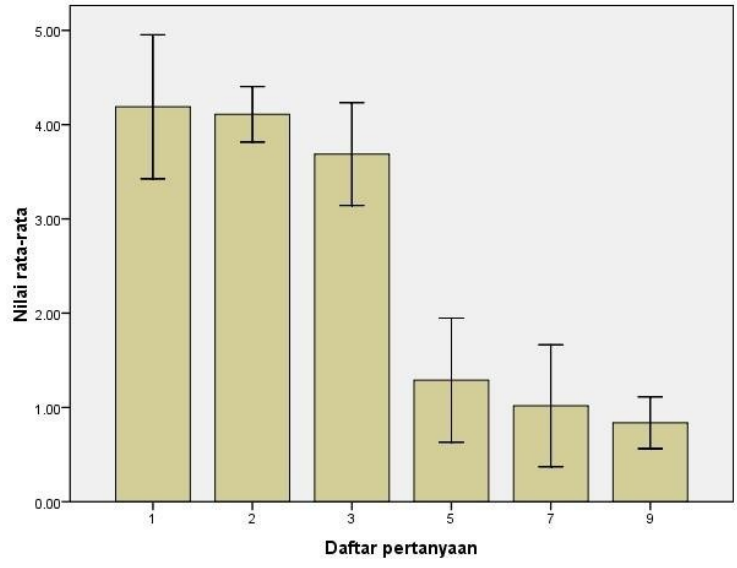

Gambar 3. Hasil evaluasi dari pertanyaan 1, 2, 3, 5, 7, dan 9

\begin{tabular}{|c|c|c|}
\hline pertanyaan & nilai $\mathrm{r}$ & $\operatorname{ta}(\%)$ \\
\hline & jawaban "ya" & jawaban "tidak" \\
\hline 4 & 100 & 0 \\
\hline 6 & 92 & $\underline{8}$ \\
\hline 8 & 79 & 21 \\
\hline
\end{tabular}

Tabel 2. Hasil analisis faktor dari pertanyaan 1, 2, 3, 5, 7, dan 9 menggunakan metode ekstraksi PCA dan oblique rotation menggunakan Promax with Kaiser Normalization

\begin{tabular}{cccc}
\hline \multirow{2}{*}{ pertanyaanenggunakan Promax with } & \multicolumn{3}{c}{ Faktor } \\
\cline { 2 - 4 } & 1 & 2 & 3 \\
\hline P1 & .880 & -.432 & -.021 \\
\hline P7 & .537 & .517 & .129 \\
\hline P9 & -.649 & -.432 & .287 \\
\hline P3 & -.626 & .747 & -.020 \\
\hline P5 & .436 & .588 & .530 \\
\hline P2 & -.121 & -.278 & .896 \\
\hline
\end{tabular}

Tabel 3. Hasil perhitungan korelasi faktor

\begin{tabular}{|c|c|c|c|}
\hline & operabilitas & $\begin{array}{l}\text { waktu } \\
\text { tunda }\end{array}$ & $\begin{array}{c}\text { perbedaan } \\
\text { spasial }\end{array}$ \\
\hline operabilitas & 1.000 & -.156 & .116 \\
\hline waktu tunda & -.156 & 1.000 & -.184 \\
\hline $\begin{array}{c}\text { Perbedaan } \\
\text { spasial }\end{array}$ & .116 & -.184 & 1.000 \\
\hline
\end{tabular}

Tabel 4. Unjuk kerja terapi ekstremitas atas menggunakan $V R$ -

\begin{tabular}{|c|c|c|c|}
\hline pengguna & $\begin{array}{c}\text { gerakan } \\
\text { tangkap apel }\end{array}$ & $\begin{array}{c}\text { gerakan } \\
\text { hindari bom }\end{array}$ & $\operatorname{rasio}(\%)$ \\
\hline 1 & 23 & $\underline{0}$ & $\underline{92}$ \\
\hline 2 & 22 & 2 & 80 \\
\hline 3 & 22 & 1 & 84 \\
\hline 4 & $\underline{20}$ & $\underline{1}$ & $\underline{76}$ \\
\hline 5 & 21 & 1 & 80 \\
\hline 6 & $\underline{25}$ & $\underline{2}$ & $\underline{92}$ \\
\hline 7 & 22 & 3 & 76 \\
\hline 8 & $\underline{23}$ & $\underline{3}$ & $\underline{80}$ \\
\hline 9 & $\underline{24}$ & $\underline{2}$ & $\underline{88}$ \\
\hline 10 & $\underline{22}$ & $\underline{3}$ & $\underline{76}$ \\
\hline
\end{tabular}

Dari Gambar 3 dapat diketahui nilai rata-rata dari pertanyaan 1,2 , dan 3 di atas 2.5. Hal ini menunjukkan operabilitas dan kontrol dari lengan virtual pada terapi ekstremitas atas menggunakan $V R$-Bicycling dengan MT berjalan sesuai dengan lengan nyata. Sedangkan nilai rata-rata dari pertanyaan 5, 7, dan 9 adalah 0.5 , dimana hal ini menunjukkan pengaruh perbedaan spasial dan timbulnya waktu tunda pada kontrol lengan virtual terhadap lengan nyata sangat kecil.

Tabel 1. menunjukkan analisis statistik dari penderita pasca stroke yang menjawab pertanyaan nomor 4, 6, dan 8 setelah melakukan terapi ekstremitas atas menggunakan $V R$-Bicycling dengan MT. Dari Tabel 1. dapat diketahui nilai rata-rata penderita pasca stroke yang menjawab "Ya" dari pertanyaan nomor 4 dan 6 lebih besar dari 90\% yang menunjukkan pergerakan dari lengan yang nyata dapat mengontrol dengan baik pergerakan lengan virtual secara mirroring sedangkan nilai rata-rata dari pertanyaan nomor 8 kurang dari 30\% dimana hal ini menunjukkan waktu tunda dari kontrol gerakan sangat kecil sehingga gerakan lengan virtual tetap terlihat alami (natural) mendekati gerakan lengan nyata.

Terdapat tiga faktor yang diuji menggunakan analisis faktor untuk mengetahui variabel-variabel yang mempengaruhi kontrol lengan virtual pada $V R$ Bicycling dengan MT, yaitu 1) operabilitas/kontrol, 2) waktu tunda, dan 3) translation gain yang mempengaruhi perbedaan spasial. Dari Tabel 2. menunjukkan hasil analisis tiga faktor dari pertanyaan $1,2,3,5,7$, dan 9 menggunakan metode ekstraksi PCA dan rotasi faktor menggunakan Promax Kaiser Normalization. Dari Tabel 2 diketahui kotak (cell) dalam satu kolom yang diwarnai lebih gelap dengan ekstraksi faktor lebih besar dari 0.5 menunjukkan kumpulan atau pengelompokan dari variabel-variabel VR-Bicycling dengan MT yang mempengaruhi pembentukan suatu faktor. Faktor 1 beranggotakan pertanyaan nomor 1, 7, dan 9 yang berhubungan dengan variabel operabilitas dari lengan virtual pada VR-Bicycling dengan MT dan perbedaan spasial dari penerapan translation gain antara lengan nyata dengan lengan virtual pada VR-Bicycling dengan MT. Sedangkan faktor 2 yang beranggotakan pertanyaan nomor 3 dan 5 berhubungan dengan seberapa natural aplikasi virtual untuk mencerminkan kondisi nyata dan waktu tunda dari lengan virtual terhadap lengan nyata. Sedangkan faktor 3 yang beranggotakan pertanyaan nomor 2 berhubungan dengan tingkat konsentrasi pengguna selama menjalankan sistem. Tabel 3. menunjukkan korelasi antar faktor-faktor yang diamati dimana faktor 3 memiliki korelasi negatif terhadap faktor 1 dan 2. Dari evaluasi analisis faktor diketahui bahwa perbedaan spasial dan waktu tunda merupakan dua variabel utama yang menjadi kunci untuk mengontrol gerakan lengan virtual pada VR-Bicycling dengan MT. Sedangkan variabel konsentrasi pengguna selama terapi walaupun bernilai cukup baik tetapi kurang memberikan pengaruh terhadap kontrol lengan virtual. Perbedaan spasial tidak menyebabkan perbedaan terlalu jauh antara VE dan lingkungan nyata, sehingga pemilihan metode translation gain sudah cukup diterapkan pada non-immersive VR. Begitu juga dengan kecilnya waktu tunda 
menjadikan gerakan lengan virtual hampir tidak memiliki jarak waktu terhadap gerakan lengan nyata sehingga menjadi lebih real-time.

Tabel 4. menunjukkan rasio unjuk kerja dari pengguna setelah melakukan terapi ekstremitas atas menggunakan VR-Bicycling yang rata-rata di atas $75 \%$. Jumlah apel dalam lintasan sepeda adalah 25 sedangkan jumlah bom dalam lintasan adalah 10 . Hal ini menunjukkan terapi gerak motorik ekstremitas atas menggunakan $V R$-Bicycling dengan MT dapat mempengaruhi persepsi diri (selfimmersion) lebih mendalam terhadap gerakan lengan dalam VE.

\section{KESIMPULAN}

Pengembangan terapi VR-Bicycling dengan MT dapat memperbaiki gerak motorik ekstremitas atas secara bertahap pada hemiparesis penderita pasca stroke. Dari hasil evaluasi data dari jawaban lembar pertanyaan yang diberikan kepada penderita pasca stroke setelah mencoba terapi MT pada $V R$ Bicycling untuk melatih gerak otot pada hemiparesis pada ekstremitas atas didapatkan bahwa operabilitas dan kontrol dari lengan virtual pada terapi ekstremitas atas menggunakan $V R$-Bicycling dengan MT berjalan sesuai dengan gerakan lengan nyata, dimana pengaruh perbedaan spasial dan timbulnya waktu tunda pada kontrol lengan virtual terhadap lengan nyata sangat kecil. Perbedaan waktu tunda antara gerakan lengan virtual dan lengan nyata sangat kecil, sehingga lengan virtual dapat bergerak terlihat natural. Dari hasil analisis faktor diketahui bahwa faktor waktu tunda dan faktor perbedaan spasial pada terapi ekstremitas atas menggunakan VR-Bicycling dengan MT merupakan dua variabel penting dalam mengontrol ketepatan gerakan lengan virtual terhadap lengan nyata.

\section{DAFTAR PUSTAKA}

ANGGORO, P. D. W. 2018. Kajian Interaksi Pengguna Untuk Navigasi Aplikasi Prambanan VR Berbasis Virtual Reality. Jurnal Teknologi Informasi dan Ilmu Komputer, 5(2), 239-246.

BANTON, T., STEFANUCCI, J., DURGIN, F., FASS, A., \& PROFFITT, D. 2005. The perception of walking speed in a virtual environment. Presence: Teleoperators \& Virtual Environments, 14(4), 394-406.

CANTERO-TÉLLEZ, R., NAUGHTON, N., ALGAR, L., \& VALDES, K. 2018.

Outcome measurement of hand function following mirror therapy for stroke rehabilitation: A systematic review. Journal of Hand Therapy.

CHIU, H.C. and ADA, L., 2016. Constraint-induced movement therapy improves upper limb activity and participation in hemiplegic cerebral palsy: a systematic review. Journal of physiotherapy, 62(3), pp.130-137.

DEUTSCH, J. E., MYSLINSKI, M. J., KAFRI, M., RANKY, R., SIVAK, M., MAVROIDIS, C., \& LEWIS, J. A. 2013. Feasibility of Virtual Reality Augmented Cycling for Health Promotion of People Post-Stroke. Journal of neurologic physical therapy: JNPT, 37(3).

DE VRIES, S., \& MULDER, T. 2007. Motor imagery and stroke rehabilitation: a critical discussion. Journal of rehabilitation medicine, 39(1), 5-13.

DOHLE, C., PÜLLEN, J., NAKATEN, A., KÜST, J., RIETZ, C., \& KARBE, H. 2009. Mirror therapy promotes recovery from severe hemiparesis: a randomized controlled trial. Neurorehabilitation and neural repair, 23(3), 209-217.

FARJADIAN, A. B., KONG, Q., GADE, V. K., DEUTSCH, J. E., \& MAVROIDIS, C. (2013, June). VRACK: measuring pedal kinematics during stationary bike cycling. In Rehabilitation Robotics (ICORR), 2013 IEEE International Conference on (pp. 1-6). IEEE.

FUKUMORI, S., GOFUKU, A., ISATAKE, K., \& SATO, K. 2014, October. Mirror thrapy system based virtual reality for chronic pain in home use. In Industrial Electronics Society, IECON 2014-40th Annual Conference of the IEEE (pp. 4034-4039). IEEE.

HOLDEN, M. K. 2005. Virtual environments for motor rehabilitation. Cyberpsychology \& behavior, 8(3), 187-211.

LAMONT, K., CHIN, M., \& KOGAN, M. 2011. Mirror box therapy-seeing is believing. Explore: The Journal of science and healing, 7(6), 369-372.

MASIERO, S., CELIA, A., ROSATI, G., \& ARMANI, M. 2007. Robotic-assisted rehabilitation of the upper limb after acute stroke. Archives of physical medicine and rehabilitation, 88(2), 142-149.

POWELL, W. A., \& STEVENS, B. 2013, August. The influence of virtual reality systems on walking behaviour: A toolset to support application design. In Virtual Rehabilitation (ICVR), 2013 International Conference on (pp. 270-276). IEEE.

RAMACHANDRAN, V. S. 2005. Plasticity and functional recovery in neurology. Clinical Medicine, 5(4), 368-373.

RANKY, R., SIVAK, M., LEWIS, J., GADE, V., DEUTSCH, J. E., \& MAVROIDIS, C. 2010, March. VRACK-virtual reality augmented cycling kit: Design and 
validation. In Virtual Reality Conference (VR), 2010 IEEE (pp. 135-138). IEEE.

SATO, K., FUKUMORI, S., MATSUSAKI, T., MARUO, T., ISHIKAWA, S., NISHIE, H., TAKATA, K., MIZUHARA, H., MIZOBUCHI, S., NAKATSUKA, H., MATSUMI, M., GOFUKU, A., YOKOYAMA, M., \& MORITA, K. 2010.

Nonimmersive virtual reality mirror visual feedback therapy and its application for the treatment of complex regional pain syndrome: an open-label pilot study. Pain medicine, 11(4), 622-629.

SUMMERS, J. J., KAGERER, F. A., GARRY, M. I., HIRAGA, C. Y., LOFTUS, A., \&

CAURAUGH, J. H. 2007. Bilateral and unilateral movement training on upper limb function in chronic stroke patients: a TMS study. Journal of the neurological sciences, 252(1), 76-82.

WU, C. Y., HUANG, P. C., CHEN, Y. T., LIN, K. C., \& YANG, H. W. 2013. Effects of mirror therapy on motor and sensory recovery in chronic stroke: a randomized controlled trial. Archives of physical medicine and rehabilitation, 94(6), 10231030.

YAVUZER, G., SELLES, R., SEZER, N., SÜTBEYAZ, S., BUSSMANN, J. B., KÖSEOĞLU, F., ATAY, M. B., \& STAM, H. J. 2008. Mirror therapy improves hand function in subacute stroke: a randomized controlled trial. Archives of physical medicine and rehabilitation, 89(3), 393398. 


\section{Halaman ini sengaja dikosongkan}

